\title{
Neurological disease associated with Mycoplasma pneumoniae infection. PCR evidence against a direct invasive mechanism
}

\author{
C G Fink, M Sillis, S J Read, L Butler, M Pike
}

\begin{abstract}
Aims-To investigate the pathology in patients presenting with sudden onset neurological illnesses associated with Mycoplasma pneumoniae infection. Methods-M pneumoniae infection was diagnosed by a highly rigorous interpretation of serological markers initially using complement fixation, agglutination and IgM antibodies. Confirmation of the serological diagnosis was achieved using indirect immunofluorescence for IgM, IgA, and IgG. Serum and cerebrospinal fluid (CSF) samples from these patients were examined using the polymerase chain reaction to look for evidence of $M$ pneumoniae DNA.

Results-No M pneumoniae DNA was found in any serum or CSF samples. Diagnosis of $M$ pneumoniae infection by agglutination and complement fixation antibodies was not always confirmed by indirect immunofluorescence.

Conclusion-The neurological lesions in these patients do not appear to be caused by the direct invasion of $M$ pneumoniae into the nervous system. The lesions may be an immune response to infection. Serological diagnosis of $M$ pneumoniae continues to be a laboratory problem. (f Clin Pathol: Mol Pathol 1995;48:M51-M54)
\end{abstract}

Keywords: Mycoplasma pneumoniae, PCR, neurological lesions, pathogenesis.

Department of Clinical Virology, John Radcliffe Hospital, Oxford OX3 9DU

C G Fink

Department of Paediatric Neurology

M Pike

Public Health

Laboratory

S J Read

Public Health Laboratory, West Norwich Hospital, Norwich

M Sillis

Paybody Eye Unit, Coventry and

Warwickshire

Hospital, Coventry

L Butler

Correspondence to:

Dr C G Fink.

Accepted for publication

25 November 1994
Mycoplasma pneumoniae infection in the United Kingdom occurs in epidemics lasting about 18 months, in four year cycles and with sporadic cases occurring in the community between epidemics. It is primarily a pathogen of the respiratory tract causing illnesses ranging from mild upper respiratory tract symptoms to severe pneumonia and occasional unexpected death in young fit individuals. ${ }^{1-3} \mathrm{M}$ pneumoniae disease is not commonly recorded in those aged under five years, where it may be clinically inapparent, ${ }^{4}$ or in the elderly. ${ }^{5}$ It has been associated with a spectrum of non-respiratory disease in children and adults including central and peripheral nervous system lesions, ${ }^{6}$ haemolytic anaemia $^{7}$ and various skin manifestations, such as maculopapular rash and erythema-multiforme, ${ }^{8}$ generally appearing 12 to 21 days after a respiratory infection. These extrapulmonary signs are believed to be immune mediated phenomena although there are rare reports of culture of the organism from $\operatorname{skin}^{89}$ and cerebrospinal fluid (CSF). ${ }^{10}$
The pathological processes in non-respiratory $M$ pneumoniae disease remain hypothetical. An induction of autoantibodies, ${ }^{11}$ changes in the glycoproteins on the red cell membrane ${ }^{1213}$ and perivascular infiltration around blood vessels ${ }^{14}$ are all suggested. The pathogenic process in respiratory disease is also still a matter for speculation. ${ }^{15}$

A major problem in the diagnosis of $M$ pneumoniae infection is that conflicting laboratory results may occur. ${ }^{1617}$ The polymerase chain reaction (PCR) can be a very sensitive technique for detecting any mycoplasma DNA in clinical samples ${ }^{18}$ and offers the possibility of quicker diagnosis earlier in the course of the disease and is a potential refinement to any investigation of the pathological processes.

\section{Methods}

SELECTION CRITERIA

Patients were selected from those presenting with acute and unexplained neurological symptoms in the Oxford region, at the Coventry and Warwickshire Hospital, Coventry, and the General Hospital, High Wycombe (tables 1 and 2). Of the 11 patients, three had sixth nerve palsy, two had third nerve palsy, two had transverse myelitis, one had optic neuritis, one had choreiform movements, one had GuillainBarre syndrome, and one had a right-sided hemiplegia. They were screened on referral for enteroviruses, Epstein-Barr virus, mumps, measles, cytomegalovirus, herpes simplex virus types 1 and 2 , and varicella zoster virus using serology and isolation techniques as appropriate for the organisms screened. Patients with evidence of viral or recent bacterial infections, including $Q$ fever, Legionella and psittacosis, were excluded from this study.

\section{LABORATORY DIAGNOSIS OF MYCOPLASMA} PNEUMONIAE INFECTION

An initial suspicion of recent infection with $M$ pneumoniae was based on clinical presentation, together with an agglutinating antibody titre of 100 or greater to mycoplasma antigen, using a Serodia-Myco-II gelatin particle agglutination test (Fujirebio, Japan). A further agglutination titre at this level or an increase to this titre or above in a second serum sample at least seven days later was considered significant. A complement fixation antibody (Behringwerke AG, Marburg, Germany) was used in conjunction with the agglutination test as a further marker of possible recent infection, taking a minimum antibody level of $1 / 128$ in the first serum sample or this level in both samples, or a fourfold 
Table 1 Patients with neurological lesions and serological and sero-immunofluorescent evidence of $M$ pneumoniae infection

\begin{tabular}{|c|c|c|c|c|c|c|c|c|c|}
\hline \multirow{2}{*}{$\begin{array}{l}\text { Patient } \\
\text { initials }\end{array}$} & \multirow{2}{*}{$\begin{array}{l}\text { Age } \\
\text { (years) }\end{array}$} & \multirow{2}{*}{$\begin{array}{l}\text { Sample } \\
\text { type }\end{array}$} & \multirow[b]{2}{*}{ CFT result } & \multirow[b]{2}{*}{ Agglutination } & \multicolumn{3}{|c|}{ Antibody titre } & \multirow{2}{*}{$\begin{array}{l}\text { ELISA } \\
(I g M)\end{array}$} & \multirow{2}{*}{$\begin{array}{l}\text { Clinical } \\
\text { presentation }\end{array}$} \\
\hline & & & & & $\operatorname{Ig} M$ & $\operatorname{Ig} G$ & $\operatorname{Ig} A$ & & \\
\hline LC & 5 & $\begin{array}{l}\text { Serum } \\
\text { Serum }\end{array}$ & $\begin{array}{l}512 \\
512\end{array}$ & $\begin{array}{l}320 \\
320\end{array}$ & $>16$ & $>64$ & $>16$ & $\begin{array}{l}\text { Positive } \\
\text { Positive }\end{array}$ & $\begin{array}{l}\text { URTI and third nerve } \\
\text { palsy }\end{array}$ \\
\hline $\mathrm{HC}$ & 6 & $\begin{array}{l}\text { Serum } \\
\text { Serum } \\
\text { CSF }\end{array}$ & $\begin{array}{r}256 \\
256 \\
<2\end{array}$ & $\begin{array}{r}320 \\
320 \\
-\end{array}$ & 8 & 64 & $<4$ & $\begin{array}{l}\text { Positive } \\
\text { Positive } \\
\text { Positive }\end{array}$ & $\begin{array}{l}\text { Febrile illness and } \\
\text { episodes of right-sided } \\
\text { hemiplegia }\end{array}$ \\
\hline $\mathrm{CO}$ & 2 & $\begin{array}{l}\text { Serum } \\
\text { CSF }\end{array}$ & $\begin{array}{r}256 \\
<2\end{array}$ & $\begin{array}{r}640 \\
-\end{array}$ & $<4$ & 32 & 4 & $\begin{array}{l}\text { Positive } \\
\text { Negative }\end{array}$ & $\begin{array}{l}\text { Febrile illness then sixth } \\
\text { nerve palsy }\end{array}$ \\
\hline $\mathbf{R R}$ & 17 & $\begin{array}{l}\text { Serum } \\
\text { CSF }\end{array}$ & $>512$ & $>1280$ & $>16$ & $>128$ & $>16$ & $\begin{array}{l}\text { Positive } \\
\text { Positive }\end{array}$ & $\begin{array}{l}\text { Pneumonia followed by } \\
\text { transverse myelitis }\end{array}$ \\
\hline FW & 5 & $\begin{array}{l}\text { Serum } \\
\text { Serum }\end{array}$ & $\begin{array}{l}256 \\
256\end{array}$ & $\begin{array}{l}340 \\
340\end{array}$ & $>16$ & $>128$ & $>16$ & $\begin{array}{l}\text { Positive } \\
\text { Positive }\end{array}$ & Cerebellar ataxia \\
\hline DB & 9 & $\begin{array}{l}\text { Serum } \\
\text { Serum } \\
\text { Serum }\end{array}$ & $\begin{array}{l}128 \\
256 \\
256\end{array}$ & $\begin{array}{r}40 \\
160 \\
160\end{array}$ & $<4$ & 16 & $<4$ & $\begin{array}{l}\text { Positive } \\
\text { Positive } \\
\text { Positive }\end{array}$ & $\begin{array}{l}\text { Febrile illness followed } \\
\text { by Guillain-Barre } \\
\text { syndrome }\end{array}$ \\
\hline RB & 9 & $\begin{array}{l}\text { Serum } \\
\text { Serum }\end{array}$ & $\begin{array}{l}32 \\
16\end{array}$ & $\begin{array}{l}320 \\
320\end{array}$ & $>16$ & 8 & 32 & & $\begin{array}{l}\text { Febrile illness and third } \\
\text { nerve palsy }\end{array}$ \\
\hline
\end{tabular}

CFT = complement fixation test.

Table 2 Patients with neurological lesions but evidence of $M$ pneumoniae infection

\begin{tabular}{|c|c|c|c|c|c|c|c|c|c|}
\hline \multirow{2}{*}{$\begin{array}{l}\text { Patient } \\
\text { initials }\end{array}$} & \multirow{2}{*}{$\begin{array}{l}\text { Age } \\
\text { (years) }\end{array}$} & \multirow{2}{*}{$\begin{array}{l}\text { Sample } \\
\text { type }\end{array}$} & \multirow[b]{2}{*}{ CFT result } & \multirow[b]{2}{*}{ Agglutination } & \multicolumn{3}{|c|}{ Antibody titre } & \multirow{2}{*}{$\begin{array}{l}\text { ELISA } \\
(I g M)\end{array}$} & \multirow{2}{*}{$\begin{array}{l}\text { Clinical } \\
\text { presentation }\end{array}$} \\
\hline & & & & & $I g M$ & $\operatorname{Ig} G$ & $\operatorname{Ig} A$ & & \\
\hline CW & 4 & $\begin{array}{l}\text { Serum } \\
\text { CSF }\end{array}$ & $\begin{array}{l}16 \\
<8\end{array}$ & $\begin{array}{l}100 \\
<40\end{array}$ & $<4$ & $<4$ & $<4$ & Positive & $\begin{array}{l}\text { Febrile and sixth nerve } \\
\text { palsy }\end{array}$ \\
\hline EP & 4 & $\begin{array}{l}\text { Serum } \\
\text { Serum }\end{array}$ & $\begin{array}{l}128 \\
128\end{array}$ & $\begin{array}{l}<40 \\
<40\end{array}$ & $\begin{array}{l}<4 \\
<4\end{array}$ & $\begin{array}{l}<4 \\
<4\end{array}$ & $\begin{array}{l}<4 \\
<4\end{array}$ & $\begin{array}{l}\text { Positive } \\
\text { Positive }\end{array}$ & $\begin{array}{l}\text { URTI and transverse } \\
\text { myelitis }\end{array}$ \\
\hline $\mathbf{H J}$ & 9 & $\begin{array}{l}\text { Serum } \\
\text { Serum }\end{array}$ & $\begin{array}{l}128 \\
128\end{array}$ & $\begin{array}{l}40 \\
40\end{array}$ & $\begin{array}{l}<4 \\
<4\end{array}$ & $\begin{array}{l}<4 \\
<4\end{array}$ & $\begin{array}{l}<4 \\
<4\end{array}$ & $\begin{array}{l}\text { Positive } \\
\text { Positive }\end{array}$ & Bilateral optic neuritis \\
\hline NS & 7 & $\begin{array}{l}\text { Serum } \\
\text { Serum }\end{array}$ & $\begin{array}{l}256 \\
256\end{array}$ & $\begin{array}{l}320 \\
320\end{array}$ & $\begin{array}{l}<4 \\
<4\end{array}$ & $\begin{array}{l}<4 \\
<4\end{array}$ & $\begin{array}{l}<4 \\
<4\end{array}$ & & Sixth nerve palsy \\
\hline
\end{tabular}

CFT $=$ complement fixation test.

increase in the antibody titre between the first and second serum samples.

A $\mu$-capture enzyme linked immunosorbent assay for IgM specific to $M$ pneumoniae (Diatech Diagnostica Ltd., Israel) was used as a further marker of infection demonstrating $\operatorname{IgM}$ in one or both serum samples in some patients. Confirmation of the presumptive diagnoses of $M$ pneumoniae was undertaken using an indirect immunofluorescence assay system to detect $\operatorname{IgG}, \operatorname{IgA}$ and IgM. ${ }^{1617}$

LABORATORY CRITERIA FOR PATIENT INCLUSION Patients were included in this study if they fulfilled a minimum of one of the following criteria: complement fixation antibody for $M$ pneumoniae $\geqslant 128$ and $M$ pneumoniae IgM detected; complement fixation antibody for $M$ pneumoniae with a fourfold increase in antibody titre between acute and convalescent serum samples; complement fixation antibody for $M$ pneumoniae $\geqslant 128$ and an agglutination titre $\geqslant 100 ; M$ pneumoniae agglutination titre $\geqslant 100$ and detection of $M$ pneumoniae specific IgM (All $M$ pneumoniae IgM initially measured by $\mu$-capture).

\section{PCR FOR M PNEUMONIAE}

A semi-nested PCR method using primers derived from the adhesin gene of $M$ pneumoniae has been described previously. ${ }^{18}$ The sensitivity of this system is reported to be one DNA copy per sample and it has been shown to be greater than five logs more sensitive than antigen detection or culture. where clinical investigation justified this invasive procedure. In some patients a second serum sample was not available and single or paired samples were tested. All clinical material underwent PCR amplification using primers specific for $M$ pneumoniae and was tested without prior DNA extraction. ${ }^{18}$

\section{Results}

The clinical and serological details of patients who were initially considered to have been recently infected with $M$ pneumoniae are presented in tables 1 and 2 .

Of 11 patients initially selected on clinical and specific serological criteria, seven were confirmed, by indirect immunofluorescence, as being unequivocally recently infected with $M$ pneumoniae (table 1). For the remaining four patients the diagnosis was not confirmed because the indirect immunofluorescence antibody assay did not support the complement fixation and/or agglutination test results (table 2).

$M$ pneumoniae DNA was not detected by PCR in any of the serum or CSF samples examined.

Six of the seven patients with confirmed $M$ pneumoniae infection and three of the remaining four patients reported a febrile illness or upper respiratory tract infection six to 14 days before the onset of neurological symptoms. All patients had made a symptomatic recovery within one year.

\section{Discussion}

Most authors believe that a clinical diagnosis followed by early and appropriate antibiotic 
treatment ${ }^{19}$ hastens the clinical resolution of $M$ pneumoniae associated respiratory disease. ${ }^{20}$ There is still argument whether or not antibiotics influence the natural history of $M$ pneumoniae non-respiratory disease. It has been suggested that the clinical manifestations of this infection may be mediated by the host immune system or a result of peroxide production by the organism. ${ }^{421}$

In this study the resolution of the neurological lesions occurred over a variable time, but all had resolved within one year which is in agreement with earlier case reports. ${ }^{223}$ Other authors did not note the time of resolution of the lesion $\mathrm{s}^{24}$ and some recorded residual deficit years after infection. ${ }^{25}$ The small number of patients in our study prevents any valid analysis of the effect of antibiotic treatment on the rate of clinical resolution of the neurological lesions.

In the cases recorded here, six of seven patients reported an episode of infection (upper respiratory tract infection (URTI) or fever) within 14 days of the onset of neurological signs. A prodrome of a respiratory infection 10 to 21 days before the onset of neurological disease is well described, ${ }^{16}$ but neurological lesions are known to appear without respiratory involvement ${ }^{26}$ and without recorded fever.

An accurate laboratory diagnosis of $M$ pneumoniae is important because of the variable clinical presentation of mycoplasma infection which often mimicks that of other common pathogens. Early and reliable diagnosis of infection is essential for any therapeutic advantage, to enable study of the disease process and for epidemiological information.

Laboratory diagnosis continues to be a problem: the organism is fastidious and slow growing and culture takes up to four weeks ${ }^{16}$ which is of limited value for clinical purposes. Serodiagnostic methods also present problems because of the antigenic diversity of the organism which is larger than a virus, but has only about one fifth of the genetic material of a bacterium. ${ }^{27}$ The complement fixation antibody titre may be late to rise after infection and may result from cross-reaction with other organisms or host material. ${ }^{28}$ Agglutination tests can produce false positive results and there may or may not be an IgM response. ${ }^{16}$ An immunofluorescence assay to detect $M$ pneumoniae specific IgM, IgA ${ }^{17}$ and $\operatorname{IgG}$ was chosen as the definitive test as it has been thoroughly evaluated in different patient populations and directly compared with respiratory culture results from the same patients. It is a labour intensive and skilled technique and is available only in specialist laboratories. Therefore, we used this test in this series as a final arbiter of infection, whilst applying a new and simple PCR $M$ pneumoniae DNA detection system to gain more insight into mycoplasma associated pathology.

In contrast to a recently reported series ${ }^{24}$ we applied strict serodiagnostic criteria in selecting patients for this study. Using these criteria for laboratory diagnosis of $M$ pneumoniae infection we excluded four patients who may, in other series, have been assumed to have sustained neurological lesions associated with $M$ pneu- moniae infection. As there are many opinions on the criteria required for the laboratory diagnosis of $M$ pneumoniae, PCR was performed on all serum and CSF samples from the 17 patients.

The PCR diagnostic system is an exquisitively sensitive and specific test for the detection of $M$ pneumoniae specific DNA. ${ }^{18}$ Negative findings in this series adds weight to the theory that $M$ pneumoniae associated neurological disease may be an immune mediated host response ${ }^{4}$ or possibly caused by release of toxic substances at the cell surface ${ }^{21}$ following elimination of the organism. Another possible mechanism for the neural pathology could be temporary occlusion of small blood vessels, ${ }^{22}$ a hypothesis advanced after observing the clinical development of third nerve palsy in one patient. This particular observation is supported by the reported pathology of perivascular inflammation observed in experimental $M$ pneumoniae infection. ${ }^{14}$

A further M pneumoniae epidemic is expected in the United Kingdom in 1994-95. Collection of reliable epidemiological data relating to transmission of the organism will require sensitive and specific diagnostic methods with strict criteria for positivity. As PCR is a highly specific and very sensitive detection system, now simplified for routine use, ${ }^{18}$ data on the prevalence of $M$ pneumoniae collected by population survey using PCR on throat swabs may test the observation that there may be passive carriage of the organism. ${ }^{29}$ Such a survey together with defined serological diagnostic criteria may provide some insight into this enigmatic organism.

1 Clyde WA Jr. Mycoplasma pneumoniae infections of man In: The mycoplasmas. Vol II. New York: Academic Press, 1979:275-306.

2 Miller AC, Hanson GC. Respiratory failure due to Mycoplasma pneumoniae in young adults. BMF 1983;287: 1028

3 Murray HW, Masur M, Senterfit LB, Roberts RB. The protean manifestations of Mycoplasma pneumoniae infections in adults. Am $\mathcal{F}$ Med 1975;58:229-42.

4 Jacobs E. Mycoplasma pneumoniae: virulence factors and the immune response. Rev Med Microbiol 1991;2:83-90.

5 Denny FW, Clyde WA, Glezan WP. Mycoplasma pneumoniae disease: clinical spectrum, pathophysiology, epidemiology and control. $\mathcal{f}$ Infect Dis 1971;123:74-92.

6 Rothstein TL, Kenny GE. Cranial neuropathy, myeloradiculopathy and myositis. Complications of $\mathrm{My}$ coplasma pneumoniae infection. Arch Neurol 1980;36: coplasm

7 Koletsky RJ, Wanskin AJ. Fulminant Mycoplasma pneumoniae infection. Report of a fatal case and review of the literature. Am Rev Respir Dis 1980;122:491-6.

8 Lyell A, Gordon AM, Dick HM, Sommerville RG. Mycoplasmas and erythema multiforme. Lancet 1967;ii: 1116 8.

9 Meseguer MA, De Rafael L, Vidal ML. Stevens-Johnson syndrome with isolation of Mycoplasma pneumoniae from skin lesions. Eur $\mathcal{f}$ Clin Microbiol 1986;5:167-8.

10 Fleischhauer P, Huben U, Mertens H, Sethi KK, Thurmann D. Nachweis von Mycoplasma pneumoniae im Liquor bei D. Nachweis von Mycoplasma pneumoniae im Liquor bei
akuter polineuritis. Dtsch Med Wochenschr 1972;97:67882 .

11 Biberfield G. Antibodies to brain and other tissues in cases of Mycoplasma pneumoniae infection. Clin Exp Immunol 1971;8:319-33.

12 Smith C, McGinniss M, Schmidt P. Changes in erythrocyte I-agglutinogen and anti-I agglutinins during Mycoplasma pneumoniae infection in man. $\mathcal{F}$ Immunol 1967;99:333-9.

13 Feizi T, Taylor-Robinson D. Cold agglutinins, anti-I and Mycoplasma pneumoniae. Immunology 1967;13:405-9.

14 Brunner $\mathrm{H}$. Studies on the pathogenesis of experimental Mycoplasma pneumoniae in the guinea pig. INSERM 1974;33:411-19.

15 Krause DC, Taylor-Robinson D. Mycoplasmas which infect humans. In: Maniloff J, ed. Mycoplasmas: molecular biology and pathogenesis. Washington DC: American Society of and pathogenesis. Wash

16 Sillis M. Modern methods for diagnosis of Mycoplasma pneumoniae. Rev Med Microbiol 1993;4:24-31.

17 Sillis M. The limitations of IgM assays in serological diag- 
nosis of Mycoplasma pneumoniae infections. $\mathrm{F}$ Med Microbiol 1990;33:253-8.

18 Fink CG, Read SJ, Sillis M. Detection of Mycoplasma pneumoniae by direct sample polymerase chain reaction (PCR) - a simple system for clinical application. $B r \mathcal{F}$ Biomed Sci 1995 (in press).

19 Shames JM, George RB, Holliday WB, Rasch JR, Mogabgab WJ. Comparison of antibiotics in the treatment of Mycoplasma pneumoniae. Arch Intern Med 1970;125:680-4.

20 Couch RB. Mycoplasma pneumoniae. In: Mandell GL, Douglas RG, Bennett JE, eds. Principles and practice of infectious diseases. New York. Churchill Livingstone, 1990

21 Koskiniemi M. CNS manifestations associated with Mycoplasma pneumoniae infections. Summary of cases at the University of Helsinki and review. Clin Infect Dis 1993; 17(Suppl 1):S52-7.

22 Fink CG, Butler L. A cranial nerve palsy associated with Mycoplasma pneumoniae infection. Polymerase chain reaction evidence against an infectious mechanism. $\mathrm{Br} F$ Ophthalmol 1993;77:750-1.

23 Fernandez CV, Bortolussi R, Gordon K, Spencer HS, Gatien
JG, Shadrabadi MS. Mycoplasma pneumoniae infection associated with CNS complications. F Child Neurol 1993; 8:27-31.

24 Thomas NH, Collins JE, Robb SA, Robinson RO. Mycoplasma pneumoniae infection and neurological disease. Arch Dis Child 1993;69:573-6.

25 Lerer RJ, Kalavsky SM. CNS disease associated with Mycoplasma pneumoniae infection. Paediatrics 1973;52:65969.

26 Scully RE, Mark EJ, McNeely BU. Case Records Editorial, Massachusetts General Hospital. N Engl f Med 1981;305 $507-14$

27 Razin S. Mycoplasma: taxonomy and ecology. In: Maniloff J, ed. Mycoplasmas: molecular biology and pathogenesis. Washington DC: American Society of Microbiology, 1992

28 Wreghitt TG. Mycoplasma pneumoniae. In: MorganCapner P, ed. Current topics in clinical virology. London: Public Health Laboratory Service, 1991.

29 Gnarpe J, Lundback A, Sunderlof B, Gnarpe H. Prevalence of Mycoplasma pneumoniae in subjectively healthy individuals. Scand $尹$ Infect Dis 1992;24:161-4. 